\title{
Characteristics of White Charcoal Produced from the Charcoal Kiln for Thermotherapy ${ }^{1}($ iop
}

\author{
Gu Joong Kwon ${ }^{2} \cdot$ Ah Ran $\mathrm{Kim}^{2} \cdot$ Hee Soo Lee ${ }^{2} \cdot$ Seung Hwan Lee ${ }^{2}$. \\ Wahyu Hidayat $^{3} \cdot$ Fauzi Febrianto $^{4} \cdot$ Nam Hun Kim (iD ${ }^{2, \dagger}$
}

\begin{abstract}
In this study, the characteristics of the white charcoal from charcoal kilns made for both charcoal production and thermotherapy and from the traditional charcoal kiln were compared and examined. A charcoal kiln for thermotherapy as a secondary purpose was made to minimize environmental problems such as fine dust and harmful gas generated from sealed charcoal kiln in consideration of comfort and safety. White Charcoal produced from the charcoal kiln for both charcoal production and thermotherapy had higher ash and volatile matter and lower fixed carbon than that from the traditional charcoal kiln. The density of the white charcoal produced from the charcoal kiln for both charcoal production and thermotherapy was slightly higher than that of the traditional one, but the equilibrium moisture content and $\mathrm{pH}$ were not significantly different. The calorific value, refinement degree, hardness and anatomical structure were not different between the two. It was concluded that the white charcoal produced from the advanced charcoal kiln for thermotherapy as a secondary purpose meets the quality certification standards of Korea Forest Research Institute.
\end{abstract}

Keywords: charcoal kiln, charcoal quality, proximate analysis, thermotherapy, white charcoal

\section{INTRODUCTION}

Domestic charcoal production in 2016 is 9,156 tons, accounting for $10 \%$ of domestic demand (Korea Forest Service, 2018). Although the production of charcoal is thought to have increased due in part to recent environmental problems and increased use of fuel, it is experiencing many difficulties because of the thoughtless distribution of charcoal from Southeast Asia, lack of utilization of charcoal byproducts, excessive environmental regulations, and lack of workforce.

It is time to solve the difficulties that the charcoal manufacturers are experiencing and to find new ways to revitalize the charcoal manufacturing industry. Revitalizing the charcoal thermotherapy that Korean people have traditionally enjoyed is one of solutions. Traditionally, charcoal kilns used in producing charcoal are made of loess and stone, and in recent years, loess

\footnotetext{
${ }^{1}$ Date Received July 30, 2018, Date Accepted September 8, 2018

2 College of Forest and Environmental Sciences, Kangwon National University, Chuncheon 24341, Republic of Korea

${ }^{3}$ Faculty of Agriculture, University of Lampung, Bandar Lampung, Indonesia

${ }^{4}$ Faculty of Forestry, Bogor Agricultural University, Bogor, Indonesia

† Corresponding author: Nam Hun Kim (e-mail: kimnh@kangwon.ac.kr, ORCID: 0000-0002-4416-0554)
} 
Gu Joong Kwon $\cdot$ Ah Ran Kim $\cdot$ Hee Soo Lee $\cdot$ Seung Hwan Lee $\cdot$ Wahyu Hidayat $\cdot$ Fauzi Febrianto $\cdot$ Nam Hun Kim

bricks and red bricks have become the main materials for producing charcoal kilns. Thermotherapy is enjoyed at a temperature of around $100^{\circ} \mathrm{C}$ during the process of cooling the charcoal kiln of a high temperature after making charcoal (white charcoal). At this time, far-infrared rays are generated in a charcoal kiln. When it is irradiated to the human body, it causes resonance in the body and raises the temperature of the deep layers. Then it promotes metabolism and is helpful for treatment of chronic diseases such as stress and problems with the immune system by improving the ability to regenerate tissues. Thus, it has long been a widely used naturopathy (Fuse and Taki, 1987; Honda and Inoue, 1988). Recently, the authors have shown that farinfrared rays help mice to relieve their stress and improve their memory (Tran et al., 2016; Mai et al., 2018a, 2018b). Therefore, thermotherapy using residual heat from the charcoal kiln after the production of charcoal is a good way to revitalize the charcoal manufacturing industry and expected to get attention as one of the new healing methods.

The charcoal kilns for the production of charcoal, which is currently used for thermotherapy, has a structure suitable for the production of charcoal. Therefore, there is a need to solve environmental issues such as purification of air contaminated by fine dust inside charcoal kilns and inflow of harmful gas generated in the adjacent charcoal kilns for a safe and comfortable thermotherapy. Therefore, it is necessary to improve the structure of charcoal kilns suitable for thermotherapy, that is, a structure which can provide a pleasant indoor air quality without any inconvenience to thermotherapy users, and a safe structure without adversely affecting the quality of charcoal produced. In order to revitalize the traditional charcoal industry, the authors developed a charcoal kiln enabling thermotherapy, using ceramic materials that emit many far-infrared rays (Kim, 2015).

The authors (Kim et al., 2006; Kim and Hanna, 2006;
Kwon et al., 2012; Kwon et al., 2013) have analyzed the quality and properties of charcoal that is produced at various temperature in many ways. The superior quality of charcoal made from traditional charcoal kilns (Hwang et al., 2002; Kwon et al., 2011) was also reported.

In this study, we compared the quality of white charcoal produced from a kiln developed to be suitable for both charcoal production and thermotherapy by improving traditional kilns with that of white charcoal produced from a traditional kiln.

\section{MATERIALS and METHODS}

\subsection{Structure of Charcoal Kiln for both charcoal production and thermotherapy}

The structure of the charcoal kiln for both charcoal production and thermotherapy is shown in Fig. 1 (Kim, 2015). For the stability of the whole charcoal structure, first, the floor was pierced with concrete, and then it was clayed with loess to install abrasion resistant ceramic bricks and loess bricks. The charcoal kiln used lightweight ceramic bricks and cement bricks for semi-permanent use. The walls were doubled, using ceramics and loess materials such as $\mathrm{MnO}$, Mullite, $\mathrm{SiC}$ etc. that can secure stability and maximize the far-infrared radiation efficiency, and the ceiling of the charcoal kiln was built as a domed type for the improvement of the yield of charcoal and beautiful appearance. Unlike traditional charcoal kilns, two entrances were built, one for charcoal production and the other one for thermotherapy, and they are separately installed on the front and back side of the charcoal kiln to minimize the environmental issues such as fine dust generated by the poor charcoal working environment and to make thermotherapy easier. 


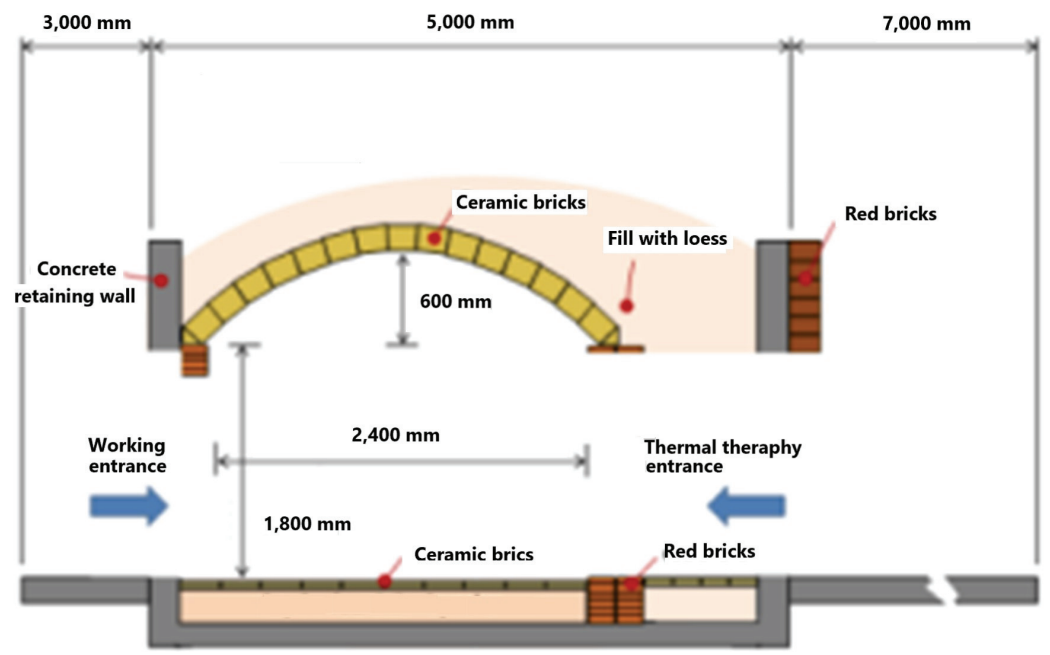

Fig. 1. Overview of a modified charcoal kiln for thermotheraphy.

\subsection{Testing materials}

In this study, white charcoal produced in the charcoal kiln for both charcoal production and thermotherapy which is installed in Paekgok-myeon, Jincheon-gun, Chungcheongbuk-do as shown in Fig. 1 and white charcoal produced in the charcoal kiln only for charcoal production built by the same company were used as testing materials.

\subsection{Experimental method}

\subsubsection{Technical analysis}

With Moisture (KS E ISO 589 anthracite-measurement of total moisture), ash (KS E ISO 1171 solid mineral fuel-measurement of ash content) and volatile matter (KS E ISO 562 anthracite and coke-crystals of volatile matter) and fixed carbons were calculated using the following equation.

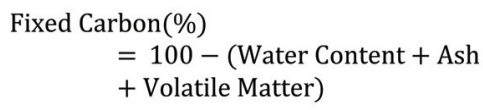

\subsubsection{Density}

The surface of the charcoal samples was covered with paraffin and then the volume was measured using a measuring cylinder containing water, and the density was calculated as follows.

$$
\begin{gathered}
\operatorname{Density}\left(\mathrm{g} / \mathrm{cm}^{3}\right)=\frac{W}{V} \times 100 \\
W=\text { Charcoal Weight }(\mathrm{g}), V=\text { Charcoal Volume }\left(\mathrm{cm}^{3}\right)
\end{gathered}
$$

\subsubsection{Hygroscopicity}

To measure the hygroscopicity of charcoal, charcoal powder pulverized to 60 mesh or less was dried in a dryer $\left(105 \pm 2^{\circ} \mathrm{C}\right)$ for 24 hours. Then, it was allowed to stand in a desiccator maintained at a relative humidity of $80 \%$ at room temperature for 24 hours to calculate the moisture absorption amount. Then, the relative humidity was adjusted using a mixture of distilled water and $\mathrm{KCl}$ (distilled water: $993.6 \mathrm{~g}, \mathrm{KCl}: 356.4 \mathrm{~g}$ ).

$$
\operatorname{Hygroscopicity}(\%)=\frac{M_{1}-M_{2}}{M_{2}} \times 100
$$

$M_{1}=$ Dried Charcoal Weight $(g)$,

$M_{2}=$ Charcoal Weight at a relative humidity of $80 \%(\mathrm{~g})$ 
Gu Joong Kwon $\cdot$ Ah Ran Kim $\cdot$ Hee Soo Lee $\cdot$ Seung Hwan Lee $\cdot$ Wahyu Hidayat $\cdot$ Fauzi Febrianto $\cdot$ Nam Hun Kim

\subsubsection{Calorific value}

The charcoal sample were pulverized to a size of $80 \mathrm{mesh}$ or less, and $0.5 \mathrm{~g}$ of the charcoal sample was placed in a calorimeter (Oxygen Bomb Calorimeter 6400, parr, USA), and then, the oxygen gas was charged to $30 \mathrm{~kg} / \mathrm{cm}^{2}$ or less and ignited to calculate the calorific value from the temperature change before and after the combustion.

\subsection{5. $\mathrm{pH}$}

About $1 \mathrm{~g}$ of the pulverized charcoal sample having a size of 60mesh or less was put into a flask, mixed with $100 \mathrm{ml}$ of distilled water, heated for 10 minutes to evaporate water, cooled by adding distilled water and measured with a pH meter (Sartorius, model PB-10).

\subsubsection{Refinement degree}

The degree of refinement was measured using a charcoal refining system (FA 56 type, Samyang Electric Company, Japan) capable of measuring an electric resistance of $10^{0}$ to $10^{8} \Omega / \mathrm{cm}$.

\subsubsection{Hardness}

The degree of scratch of the charcoal surface was analyzed by using a charcoal hardness meter (ranging from 1 to 20, Samyang Electric Company, Japan) classified into 20 categories based on the difference in hardness of metals mixed with lead, antimony, copper and zinc in a specific way. The metal piece composed of the softest lead in the hardness meter is No. 1 , and the metal piece of the hardest steel is No. 20 .

\subsubsection{Anatomical characteristics}

To observe the anatomical characteristics of charcoal, charcoal samples were observed under an accelerating voltage of $15 \mathrm{kV}$ with a scanning electron microscope (JEOL, JSM-5000).

\section{RESULTS and DISCUSSION}

\subsection{Technical analysis}

Generally, charcoal consists of water, volatile matter that is volatilized by heat, inorganic matter (ash) that remains after combustion, and fixed carbon that is not reduced by heat itself. Table 1 indicates the results of the technical analysis of the white charcoal produced from a traditional charcoal kiln and the one produced from a charcoal kiln for both charcoal production and thermotherapy. The moisture content of white charcoal produced from the traditional charcoal kiln was 9.60\% and that of white charcoal produced from the charcoal kiln for both charcoal production and thermotherapy was $9.15 \%$. Therefore, the difference between the two samples was not significant. However, Lee and Kim (2010a) reported the moisture content of white charcoal produced from the traditional charcoal kiln was $7.9 \%$ and Kwon et al. (2011) reported the water content of white charcoal produced from the charcoal kiln for both charcoal production and thermotherapy was 6 8\%, and therefore charcoal used in this study showed a slightly higher moisture content. The ash was $1.14 \%$ of white charcoal produced from the traditional charcoal kiln and $1.50 \%$ of white charcoal produced from the charcoal

Table 1. Proximate analyses of the charcoal samples

(unit : \%)

\begin{tabular}{ccccc}
\hline & Moisture content & Ash & Volatile matter & Fixed carbon \\
\hline \hline $\begin{array}{c}\text { Charcoal from a } \\
\text { modified kiln for } \\
\text { thermotheraphy }\end{array}$ & $9.15 \pm 0.01$ & $1.50 \pm 0.12$ & $9.10 \pm 3.75$ & $80.19 \pm 3.80$ \\
\hline $\begin{array}{c}\text { Charcoal from a } \\
\text { traditional kiln }\end{array}$ & $9.60 \pm 0.04$ & $1.14 \pm 0.03$ & $7.06 \pm 1.69$ & $82.20 \pm 1.68$ \\
\hline
\end{tabular}


Table 2. Density, pH, and EMC of the charcoal samples

\begin{tabular}{lccc}
\hline & Density $\left(\mathrm{g} / \mathrm{cm}^{3}\right)$ & $\mathrm{pH}$ & EMC $(\%)$ \\
\hline \hline $\begin{array}{l}\text { Charcoal from a } \\
\text { modified kiln for } \\
\text { thermotheraphy }\end{array}$ & $0.47 \pm 0.04$ & $9.29 \pm 0.06$ & $9.88 \pm 0.04$ \\
\hline $\begin{array}{l}\text { Charcoal from a } \\
\text { traditional kiln }\end{array}$ & $0.45 \pm 0.07$ & $9.59 \pm 0.02$ & $10.85 \pm 0.04$ \\
\hline
\end{tabular}

1) EMC : Equilibrium moisture content

kiln for both charcoal production and thermotherapy. Kwon et al. (2011) estimated the ash content to be 1.63 to $2.71 \%$, and Lee and Kim (2010a) estimated the ash content to be to $2.5 \%$, and Kwon et al. estimated the peripheral charcoal to be $2.67 \%$ and the central charcoal to $3.10 \%$. Therefore, white charcoal in this study showed a somewhat low ash content. The volatile matter of white charcoal from the traditional kiln was $7.05 \%$, and that of white charcoal from the charcoal kiln for both charcoal production and thermotherapy was $9.10 \%$, which is a little higher. The content of volatile matter was slightly different so Lee and Kim (2010a) reported 9.9\%, while Kwon et al. (2011) reported $3.4 \%$. Fixed carbon was $82.20 \%$ for the charcoal kiln only for charcoal production and 80.19\% for the charcoal kiln for both charcoal production and thermotherapy. Kwon et al. (2011) reported that the average fixed carbon of white charcoal was $87 \%$, and Lee and Kim (2010a) reported it was 79.3\%. The amount of fixed carbon of white charcoal in this study was not significantly different from that of general charcoal. The charcoal used in this study showed excellent properties that meet the quality certification standards
(National Institute of Forest Science, 2017) of wood products (No. 2017-9) notified by the Korea Forest Research Institute.

\subsection{Density, $\mathrm{pH}$, hygroscopicity}

Table 2 shows the density, $\mathrm{pH}$, and hygroscopicity of the charcoal produced from the charcoal kiln only for charcoal production and the white charcoal produced from the charcoal kiln for both charcoal production and thermotherapy. The density of the white charcoal produced from the traditional charcoal kiln was 0.45 $\mathrm{g} / \mathrm{cm}^{3}$, and that of the white charcoal produced from the charcoal kiln for both charcoal production and thermotherapy was $0.47 \mathrm{~g} / \mathrm{cm}^{3}$, which is slightly higher than that of the white charcoal produced from the traditional charcoal kiln $\mathrm{pH}$ was 9.29 for the charcoal kiln only for charcoal production and $9.59 \%$ for the charcoal kiln for both charcoal production and thermotherapy. In general, charcoal properties are strongly influenced by carbonization temperature, and $\mathrm{pH}$ is inclined to be alkaline with the carbonization temperature increasing (Jo et al., 2008). Kwon et al.

Table 3. Calorific value, refining degree, and hardness of the charcoal samples

\begin{tabular}{|c|c|c|c|}
\hline & $\begin{array}{c}\text { Calorific value } \\
\text { (kcal/kg) }\end{array}$ & Refining degree & Hardness \\
\hline $\begin{array}{l}\text { Charcoal from a } \\
\text { modified kiln for } \\
\text { thermotherapy }\end{array}$ & $8,139 \pm 41$ & $0 \sim 1$ & 12 \\
\hline $\begin{array}{l}\text { Charcoal from a } \\
\text { traditional kiln }\end{array}$ & $8,095 \pm 13$ & $0 \sim 1$ & 12 \\
\hline
\end{tabular}


Gu Joong Kwon $\cdot$ Ah Ran Kim $\cdot$ Hee Soo Lee $\cdot$ Seung Hwan Lee $\cdot$ Wahyu Hidayat $\cdot$ Fauzi Febrianto $\cdot$ Nam Hun Kim

(2012, 2013) reported that using an oriental oak, the $\mathrm{pH}$ of charcoal increased with increasing carbonization temperature, showing strong alkalinity. Recently, Hidayat et al. (2017) reported an increase in $\mathrm{pH}$ with increasing carbonization temperature in the study of carbonization using core wood of tropical wood. Charcoal produced at such a high temperature has a high $\mathrm{pH}$. This is because of the difference in the types and amounts of the acidic or alkaline functional groups generated depending on the carbonization temperature. Another reason is believed to be that the acidic functional groups in the low-temperature carbides and the basic functional groups in the high-temperature carbides become richer (Jo et al., 2006). After analyzing the hygroscopicity of charcoal measured at a relative humidity of $80 \%$, it was found that the equilibrium moisture content of the white charcoal from the traditional kiln was $10.85 \%$, and the equilibrium moisture content of the white charcoal from the charcoal kiln for both charcoal production and thermotherapy was $9.88 \%$, so both the figures are similar. Modern houses are likely to become a sealed indoor environment due to heat insulation and sound insulation design. This sealed environment tends to be in a high humidity condition, and as a result, indoor VOCs, harmful bacteria, and fungi are problematic, so that the use of charcoal is highly recommendable because people are greatly interested in humidity control and deodorization using environmentally friendly materials (Lee and Kim, 2010a; Lee and Kim, 2010b).

\subsection{Calorific value, hardness, refinement degree}

Table 3 indicates the results of calorific value, hardness and refinement degree of the charcoal produced from a traditional charcoal kiln and the one produced from a charcoal kiln for both charcoal production and thermotherapy. The calorific value of white charcoal from the traditional charcoal kiln was $8,139 \mathrm{kcal} / \mathrm{kg}$, while that of white charcoal from the charcoal kiln for both charcoal production and thermotherapy was $8,095 \mathrm{kcal} / \mathrm{kg}$. The calorific values of the charcoal produced in the two charcoal kilns is grade A meaning an excellent product based on the quality certification standards (National Institute of Forest Science, 2017) of wood products notified by the Korea Forest Research Institute (No. 2017-9). Refining is a high-temperature treatment process that is finally performed while burning charcoal, and the quality of charcoal changes during this process. The refinement degree refers to the degree of carbonization of charcoal by measuring the electrical resistance of the surface of charcoal. It is measured in 10 steps from 0 to 9 , and the closer to 0 , the better the quality of charcoal. Also, the hardness of charcoal indicates that of the charcoal surface, and the higher the number, the harder it is. The refinement degree and hardness showed the same excellent characteristics for both the charcoals from the charcoal kiln only for charcoal production and from the charcoal kiln for both charcoal production and thermotherapy.

\subsection{Anatomical characteristics}

Fig. 2 shows photographs of three sections of charcoals produced from a traditional charcoal kiln and a charcoal kiln for both charcoal production and thermotherapy, and these photographs were observed by a scanning electron microscope. Generally, the cross-sections of the charcoals are almost the same as those of wood, but the cell walls have a homogeneous structure, and the shape of the duct is tangentially or radially deformed or distorted a little. Spinning and tangential sections are not much different from those of wood, and the wall of each cell is homogeneous and shows an amorphous form. It has been reported that the structure of charcoal varies with the manufacturing temperature (McGinnes et al., 1971; 


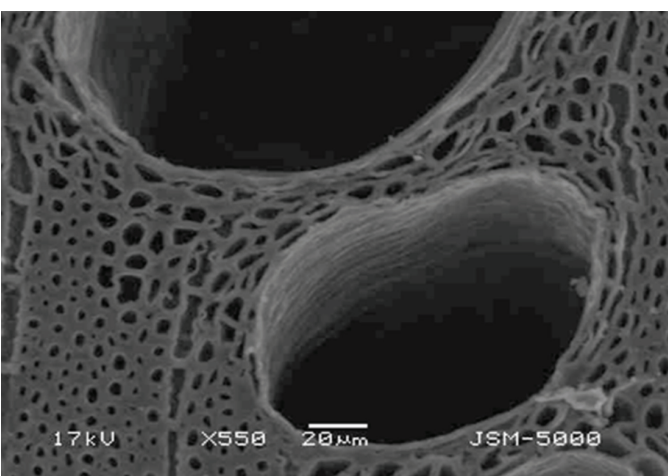

(A)

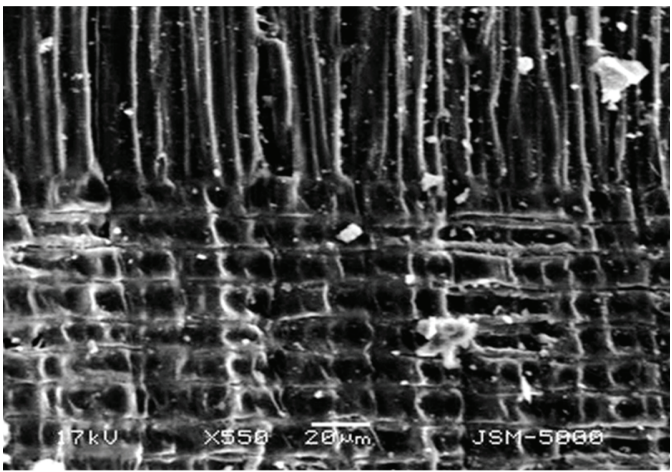

(C)

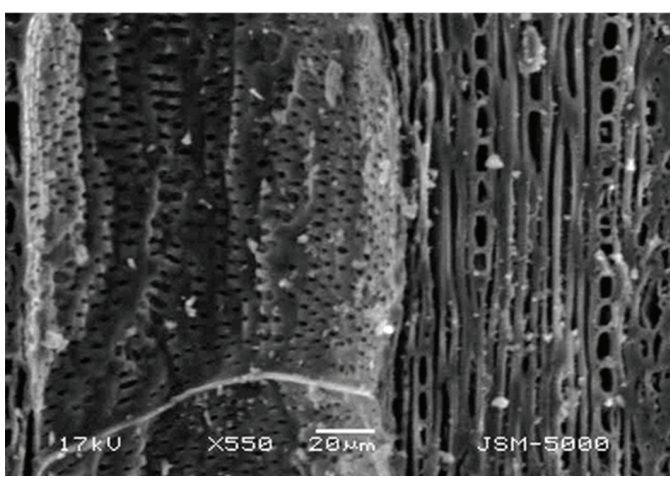

(E)

Kiln for thermotherapy

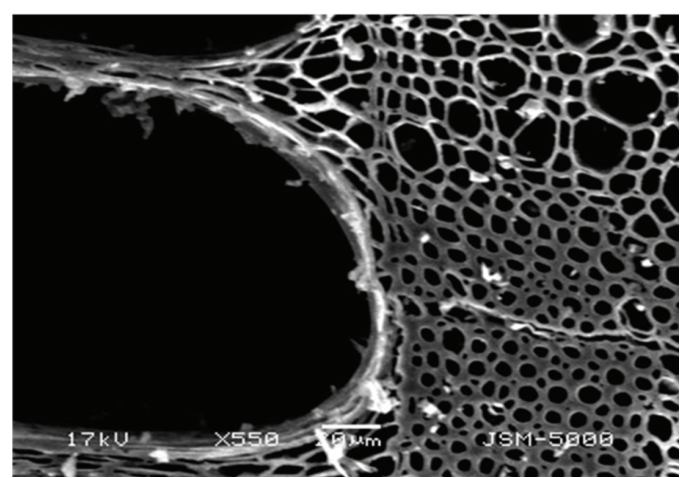

(B)

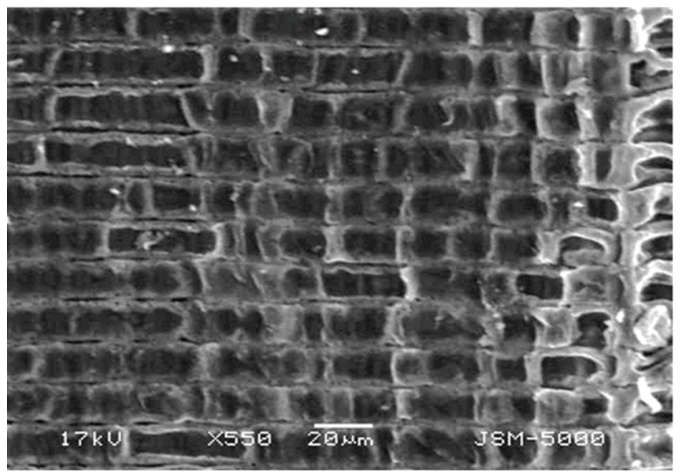

(D)

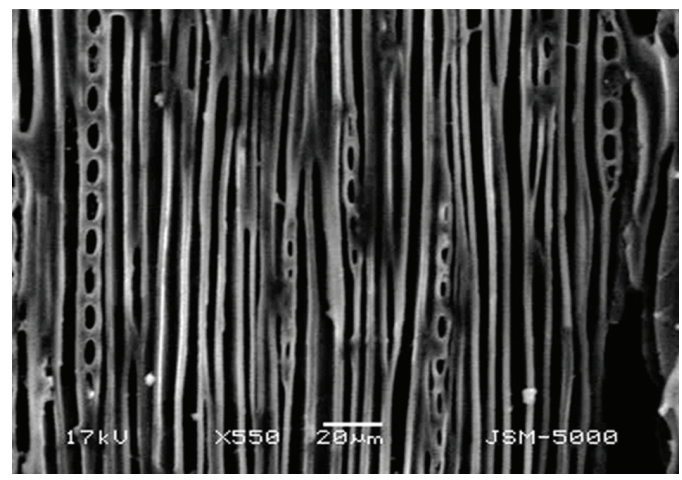

(F)

Traditional kiln

Fig. 2. SEM images on cross sections(A,B), radial sections(C,D), and tangential sections(E,F) of white charcoal from the thermotherapy and traditional kilns.

Elder et al., 1979; Cutter et al., 1980; Kim and Hanna, 2006; Kwon et al., 2009 ), and archaeological aspects have also been studied in relation to the identification of species (Prior and Alvin, 1983, 1986; Prior and Gasson, 1993; Angeles, 2001; Eom and Xu, 2010). The authors (Kim and Hanna, 2006) studied the difference 
Gu Joong Kwon $\cdot$ Ah Ran Kim $\cdot$ Hee Soo Lee $\cdot$ Seung Hwan Lee $\cdot$ Wahyu Hidayat $\cdot$ Fauzi Febrianto $\cdot$ Nam Hun Kim

in the anatomical characteristics based on the manufacturing temperature from the results of the scanning electron microscope analysis of charcoal which was produced at various temperatures. In other words, charcoal produced at $1000^{\circ} \mathrm{C}$, which is almost the same temperature used for white charcoal in this study, made ducts and parenchymatous cells greatly destroyed and deformed and cell walls much thinner than charcoal produced at $400-800^{\circ} \mathrm{C}$. Besides, the surface of calcium crystals in wood has a smooth appearance on charcoal which is produced at 400$600^{\circ} \mathrm{C}$, but, in the case of charcoal produced at 800$1000^{\circ} \mathrm{C}$, small voids appear on the surface of calcium crystals.

\section{CONCLUSION}

The results of the study on the characteristics of the white coal produced from a traditional kiln and the one produced from a charcoal kiln for both charcoal production and thermotherapy are as follows.

1. According to the technical analysis of the white charcoal produced from the traditional charcoal kiln and the one from the charcoal kiln for both charcoal production and thermotherapy, the moisture content was less than $10 \%$, the ash content was less than $3 \%$, the volatile content was less than $10 \%$, and the fixed carbon was more than $80 \%$, which means an excellent quality.

2. The density was $0.45 \mathrm{~g} / \mathrm{cm}^{3} \sim 0.47 \mathrm{~g} / \mathrm{cm}^{3}$, and the $\mathrm{pH}$ was 9.29 to 9.59 , and the hygroscopicity was about $10 \%$ at a relative humidity of $80 \%$ so there was little difference between the white charcoals of the two kilns.

3. The calorific value was more than $8000 \mathrm{kcal}$, the refinement degree was 0 , and the hardness was 12 so there was little difference between the white charcoals of the two kilns, which means an excellent quality.
4. There was no difference in the structure of the three sections observed by a scanning electron microscope.

Based on the above results, it can be concluded that white charcoal produced from the charcoal kiln for both charcoal production and thermotherapy has the characteristics similar to those of white charcoal produced from the traditional charcoal kiln.

\section{ACKNOWLEDGMENT}

This study was supported by the Forestry Science and Technology Research and Development Project (Project No: 2016008A00-1719-AB01) provided by the Korea Forest Service.

\section{REFERENCES}

Angeles, G. 2001. New techniques for the anatomical study of charcoalified wood. IAWA Journal 22(3): 245-254.

Cutter, B.E., Cumbie, B.G., McGinnes, E.A. Jr. 1980. SEM and shrinkage analyses of southern pine wood following pyrolysis. Wood Science and Technology 14: 115-130.

Elder, T.J., Murphey, W.K., Blankenhorn, P.R. 1979. A note on the thermally induced changes of intervessel pits in black cherry (Prunus serotina EHRH.). Wood Fiber 11(3): 179-183.

Eom, Y.G., Xu, G.Z. 2010. Wood identification of neolithic charcoal excavated at giheung nongseori ruins. Journal of the Korean Wood Sciences and Technology 38(4): 275-281.

Fuse, T., Taki, M. 1987. Nonthermogenic effect of far-infrared radiation with a wavelength of $100 \mathrm{gm}$ on biological organisms. Sekigaisen Gijutsu 12: 27-34.

Hidayat, W., Qi, Y., Jang, J.H., Febrianto, F., Lee, S.H., 
Chae, H.M., Kondo, T., Kimn N.H. 2017. Carbonization characteristics of juvenile woods from some tropical trees planted in indonesia. Journal of the Faculty of Agriculture Kyushu University 62 (1): 145-152.

Honda, K., Inoue, S. 1988. Sleep-enhancing effects of far-infrared radiation in rats. International Journal of Biometeorology 32: 92-94.

Hwang, W.J., Kwon, G.J., Lee, S.J., Park, H.S., Kim, N.H. 2002. Anatomical characteristics of charcoals carbonized in a Korean traditional kiln. Journal of the Korean Forest Bioenergy Society 21(1): 49-55.

Jo, T.S., Lee, O.K., Ahn, B.J., Choi, J.W. 2006. Some physical properties and adsorptive behaviors of wood charcoal carbonized with domestic wood. Journal of the Korean Forest Bioenergy Society 25(1): 9-17.

Jo, T.S., Lee, O.K., Choi, J.W., Byun, J.K. 2008. Adsorption of cardmium ion by wood charcoal prepared with red oak(Quercus mongolica). Journal of the Korean Wood Sciences and Technology 36(3): 93-100.

Kim, N.H. 2015. A study on the practical utilization to thermal therapy of charcoal kiln for revitalization of the traditional wood charcoal industry. Korea forest service. pp1-91.

Kim, N.H., Hanna, R.B. 2006. Morphological characteristics of Qurecus variabilis charcoal prepared at different temperatures. Wood Science and Technology 40: 392-401.

Kim, N.H., Hwang, W.J., Kwon, S.M., Kwon, G.J., Lee, S.J. 2006. Anatomy of Quercus variabilis charcoal manufactured at various temperature. Journal of the Korean Wood Sciences and Technology 34(4): 1-8.

Korea Forest Service. 2018. 2016 Wood utilization survey.

Kwon, G.J., Kwon, S.M., Jang, J.H., Hwang, W.J., Kim, N.H. 2011. Charcoal properties and temperature change of a kiln's inner and outer walls in carbonization process using an improved kiln. Journal of the Korean Wood Sciences and Technology 39(3): 230-237.

Kwon, S.M., Jang, J.H., Lee, S.H., Park, S.B., Kim, N.H. 2013. change of heating value, $\mathrm{pH}$ and FT-IR spectra of charcoal at different carbonization temperatures. Journal of the Korean Wood Sciences and Technology 41(5): 440-446.

Kwon, S.M., Kim, N.H., Cha, D.S. 2009. An investigation on the transition characteristics of the wood cell walls during carbonization. Wood Science and Technology 43: 487-498.

Kwon, S.M., Kwon, G.J., Jang, J.H., Kim, N.H. 2012. Characteristics of charcoal in different carbonization temperatures. Journal of Forest Science 28(4): 263-267.

Lee, D.Y., Kim, B.R. 2010a. Adsorption characteristics of commercial wood charcoal (I). Journal of the Korean Wood Sciences and Technology 38(1): 27-35.

Lee, D.Y., Kim, B.R. 2010b. Analysis of functional characteristics of the commercial wood charcoal in Korea. Journal of the Korean Wood Sciences and Technology 38(6): 480-489.

Mai, H.N., Sharma, N., Shin, E.J., Nguyen, B.T., Jeong, J.H., Jang, C.H., Cho, E.H., Nah, S.Y., Kim, N.H., Nabeshima, T., Kim, H.C. 2018a. Exposure to far infrared ray protects methamphetamine-induced behavioral sensitization in glutathione peroxidase-1 knockout mice via attenuating mitochondrial burdens and dopamine D1 receptor activation. Neurochemical Research 43: 1118-1135.

Mai, H.N., Sharma, N., Shin, E.J., Nguyen, B.T., Nguyen, P.T., Jeong, J.H., Cho, E.H., Lee, Y.J., Kim, N.H., Jang, C.G., Nabeshima, T., Kim, H.C. 2018b. Exposure to far-infrared ray attenuates methamphetamine-induced impairment in recognition memory through inhibition of protein 
Gu Joong Kwon $\cdot$ Ah Ran Kim $\cdot$ Hee Soo Lee $\cdot$ Seung Hwan Lee $\cdot$ Wahyu Hidayat $\cdot$ Fauzi Febrianto $\cdot$ Nam Hun Kim

kinase $\mathrm{C} \delta$ inmale mice: Comparison with the antipsychotic clozapine. Journal of Neuroscience Research 96: 1294-1310.

McGinnes, E.A., Jr, Kandeel, S.A., Szopa, P.S. 1971. Some structural changes observed in the transformation of wood into charcoal. Wood Fiber 3(2): 77-83

National Institute of Forest Science. 2017. Standard and specification of wood products. Notification No. 2017-9 of the National Institute of Forest Science. Prior, J., Alvin, K.L. 1983. Structural changes on charring woods of dichrostachys and salix from southern Africa. International Association of Wood Anatomists Bulletin 4(4): 197-206.

Prior, J., Alvin, K.L. 1986. Structural changes on charring woods of dichrostachys and salix from southern Africa: the effect of moisture content. International Association of Wood Anatomists Bulletin 7(3): 243-250.

Prior, J., Gasson, P. 1993. Anatomical changes on charring six African hardwoods. International Association of Wood Anatomists Journal 14(1): 77-86.

Tran T.H., Mai, H.N., Shin, E.J., Nam, Y.S., Nguyen, B.T., Lee, Y.J., Jeong, J. H., Tran H.Y., Cho, E.H., Nah, S.Y., Lei, X.G., Nabeshima, T., Kim, N.H., Kim, H.C. 2016. Repeated exposure to far infrared ray attenuates acute restraint stress in mice via inhibition of JAK2/STAT3 signaling pathway by induction of glutathione peroxidase- 1 . Neurochemistry International 94: 9-22. 


\title{
APPENDIX
}

\author{
(Korean Version)
}

\section{온열욕 겸용 숯가마에서 생산된 백탄의 특성}

요약 : 본 연구에서는 온열욕 겸용을 위해 제작한 솣가마와 전통식 솣가마에서 제조한 백탄의 특성에 대해서 비교, 검토하였다. 온열욕 겸용 숯가마는 밀폐된 숯가마에서 발생하는 미세먼지 및 유해가스와 같은 환경문제를 최소화하고 편안함과 안전성을 고려하여 제작하였다. 온열욕 겸용 솣가마에서 제조한 백탄은 전통식 숯가마의 백탄보다 회분과 휘발분이 다소 높았고 고정탄소 가 다소 낮았다. 온열욕 겸용 숯가마에서 생산된 백탄의 밀도는 기존의 전통식 솣가마 백탄보다 약간 높았지만, 평형함수율과 $\mathrm{pH}$ 는 거의 차이가 없었다. 발열량, 정련도, 경도와 해부학적 구조는 숯가마에 따른 차이가 없었다. 결론적으로 온열욕 겸용을 위해 개량된 솣가마에서 제조한 백탄은 국립산림과학원의 품질인증기준을 충족하였고, 온열욕 겸용 솣가마는 목탄제조에도 적합한 것으로 판단되었다.

\section{1. 서 론}

2016년의 국내 목탄생산량은 9,156톤으로 국내 수요의 10\%정도를 차지하고 있다(Korea Forest Service. 2018). 목탄생산량 은 최근 환경문제 해결 및 연료용 사용량 증가로 인해 다소 증가하고 있는 것으로 생각되지만, 동남아산 숯의 무분별한 유통, 숯 부산물 등의 활용처 부족, 지나친 환경규제, 인력수급문제 등으로 인해 목탄제조업은 많은 어려움을 겪고 있다.

이러한 목탄제조업체의 애로사항을 해소하고, 목탄제조 산업의 부활을 도모할 수 있는 새로운 방안이 필요한 시점에 있다. 그 방안의 하나가 우리 민족이 전통적으로 즐겨온 숯가마 온열욕의 활성화이다. 전통적으로 목탄제조에 사용되는 숯가마는 황토와 돌을 이용하여 제작하였고, 최근에는 황토벽돌과 적벽돌이 솣가마 제작용 주요 소재가 되고 있다. 온열욕은 숯(백탄)을 제조한 후 고열의 숯가마를 냉각하는 과정의 $100^{\circ} \mathrm{C}$ 전후의 온도에서 하게 된다. 이 때 솣가마에서는 원적외선이 발생하는데 원적외선은 인체에 조사되면 체내 진동공명을 일으켜 심층부의 온도를 상승시키고, 신진대사를 증진시키며, 조직의 재생력 등의 향상으로 스트레스 완화, 면역력 증진 등의 만성질환의 치료에 효과가 있어 오래전부터 널리 이용된 자연요법으로 알려지고 있다(Fuse and Taki, 1987; Honda and Inoue, 1988). 최근 저자 등은 마우스를 이용한 실험에서 원적외선이 스트레스완화와 기억력 향상에 도움을 준다는 것을 밝혔다(Tran et al., 2016; Mai et al., 2018a, 2018b). 따라서 목탄제조 후 숯가마의 잔열을 이용한 온열욕은 새로운 힐링방법의 하나로 주목받을 것으로 기대되며, 목탄제조산업을 활성화할 수 있는 좋은 방안으로 생각되 고 있다.

현재 온열욕에 이용되고 있는 목탄제조용 숯가마는 숯생산에 적합한 구조로 제작되어 있어서, 안전하고 쾌적한 온열욕을 위해서는 숯가마내부의 미세먼지에 의한 공기질 개선 및 인접 숯가마에서 발생하는 유해가스 유입 등의 환경적 문제를 해결할 필요성이 제기되고 있다. 이에 온열욕에 적합한 숯가마 환경 조성, 즉 온열욕 이용객에 불편함이 없는 쾌적한 실내공기질과 안전한 구조이면서 제조된 목탄의 품질에 나쁜 영향을 주지 않는 겸용이 가능한 구조로 개선해야 한다. 이에 부응하여 저자 등은 전통 숯산업의 활성화를 위하여 원적외선의 방출량이 많은 세라믹 재료를 이용하여 온열욕 겸용 솣가마 모델을 개발하였다 (Kim, 2015).

저자 등(Kim et al., 2006; Kim and Hanna, 2006; Kwon et al., 2012; Kwon et al., 2013)은 각 온도에서 제조되는 목탄의 품질과 특성에 대해서 다양한 방법으로 분석하여 왔다. 또한 전통식 솣가마에서 제조된 목탄품질의 우수성에 대해서도 보고하였 다(Hwang et al., 2002; Kwon et al., 2011).

본 연구에서는 기존의 전통식탄화로를 개선하여 온열욕과 목탄생산을 겸용으로 사용하는데 적합한 구조로 개발된 탄화로에 서 제탄된 백탄의 품질을 평가하였고, 기존의 전통식탄화로에서 제탄된 백탄의 특성과 비교, 검토하였다.

\section{2. 재료 및 방법}

2.1 온열욕 겸용 숯가마 구조

목탄을 제조한 온열욕 겸용 숯가마의 구조는 Fig. 1과 같다(Kim, 2015). 숯가마 구조물 전체의 안정성을 위하여 먼저 바닥을 
콘크리트로 타공하고 그 위에 황토다짐을 한 후, 내마모성 세라믹 벽돌 및 황토벽돌을 설치하는 구조로 바닥을 축조하였다. 숯가마는 반영구적인 수명 연장을 위하여 경량 세라믹 벽돌 및 시멘트 벽돌을 이용하였다. 벽체는 안정성의 확보와 원적외선 방사효율을 극대화 할 수 있는 $\mathrm{MnO}, \mathrm{Mullite,} \mathrm{SiC}$ 등과 같은 세라믹 과 황토소재를 이용한 2중구조로 하였으며, 숯가마의 천장은 수탄율 향상과 아름다운 외형을 발휘할 수 있도록 돔형으로 축조하였다. 출입구는 기존 숯가마와는 다르게 열악한 숯작업환경으로 인해 발생되는 미세먼지 등의 환경문제를 최소화하고 온열욕의 편이성을 위해 작업용 통로와 온열욕용 통로로 분리하여 숯가마의 전면부와 후면부에 따로 설치하였다.

\section{2 공시재료}

본 연구에서는 충청북도 진천군 백곡면에 설치된 Fig. 1 의 온열욕 겸용 숯가마에서 제탄된 백탄과 동일 업체에서 목탄생산 전용 솣가마에서 제탄된 백탄을 공시재료로 사용하였다.

\section{3 실험방법}

2.3.1. 공업분석

목탄을 60mesh 이하의 크기로 분쇄하여 목탄에 함유된 수분(KS E ISO 589 무연탄-총 수분 함량의 측정), 회분 (KS E ISO 1171 고형광물 연료-재 함량 측정), 휘발분(KS E ISO 562 무연탄과 코크스-휘발성 물질의 결정), 고정탄소를 다음과 같은 식을 이용하여 산출하였다.

\subsection{2. 밀도}

목탄시료의 표면을 파라핀으로 피복하고 물이 담긴 메스실린더를 이용하여 부피를 측정하고, 다음과 같은 식으로 밀도를 계산하였다.

\subsection{3. 흡습성}

목탄의 흡습성을 측정하기 위해 $60 \mathrm{mesh}$ 이하로 분쇄된 목탄 분말을 건조기 $\left(105 \pm 2^{\circ} \mathrm{C}\right)$ 에 24 시간 건조시킨 후, 실온에서 상대습 도 $80 \%$ 로 유지된 데시케이터에서 24시간 방치하여 흡습량을 산출하였다. 이때 상대습도는 증류수와 $\mathrm{KCl}$ 혼합액(증류수: 993.6g, KCl: 356,4g)을 사용하여 조절하였다.

\subsection{4. 발열량}

목탄시료는 80mesh 이하의 크기로 분쇄하여 $0.5 \mathrm{~g}$ 을 발열량계(Oxygen Bomb Calorimeter 6400 , parr, USA)에 넣고 산소가스 를 $30 \mathrm{~kg} / \mathrm{cm}^{2}$ 이하로 충전하고 점화하여 연소전·후의 온도변화로부터 발열량을 계산하였다.

\subsection{5. $\mathrm{pH}$}

$60 \mathrm{mesh}$ 이하의 크기로 분쇄된 목탄시료 약 $1 \mathrm{~g}$ 를 플라스크에 넣어서 증류수 $100 \mathrm{ml}$ 와 혼합한 후, 10 분간 가열하여 증발한 양의 증류수를 가해 냉각시키고 $\mathrm{pH}$ 측정기(Sartorius, model PB-10)로 측정하였다.

2.3.6. 정련도

$10^{0} \sim 10^{8} \Omega / \mathrm{cm}$ 의 전기 저항을 측정할 수 있는 목탄정련계(FA 56형, 삼양전기제작소, 일본)를 이용하여 측정하였다.

\subsection{7. 경도}

납, 안티몬, 동, 아연 등을 소정 배합한 금속을 경도의 차이에 의해 20종류로 구분된 목탄경도계(1 20범위, 삼양전기제작소, 일본)를 이용하여 목탄 표면을 긁힘정도를 분석하였다. 경도계에서 가장 연한 납으로 된 금속편이 1 번이고, 가장 단단한 강철의 금속편이 20 번이다.

\subsection{8. 해부학적 특성}

목탄의 해부학적 특성을 관찰하기 위하여 목탄 시편을 주사전자현미경(Scanning Electron Microscope, JEOL, JSM-5000)으 로 $15 \mathrm{kV}$ 의 가속전압 하에서 관찰하였다. 


\section{3. 결과 및 고찰}

\section{1 공업분석}

일반적으로 목탄은 수분, 가열에 휘산되는 휘발분, 연소후에도 잔류하는 무기물(회분), 가열자체로는 감량되지 않는 고정탄소 로 이루어져 있다. Table 1 은 전통식숯가마에서 생산된 백탄과 온열욕 겸용 솣가마에서 생산된 백탄에 대한 공업분석 결과이다. 함수율은 전통식솣가마 백탄이 $9.60 \%$, 온열욕 겸용 솣가마 백탄이 $9.15 \%$ 로 두 시료간의 차이는 크지 않은 것으로 나타났다. 그러나 Lee and Kim(2010a)은 전통식탄화로에서 제탄된 백탄의 함수율이 7.9\%, Kwon et al.(2011)은 개량형 전통식탄화로에서 생산된 백탄의 함수율을 6 8\%로 보고하고 있어, 본 연구에 이용한 목탄은 약간 높은 함수율을 보여주었다. 회분은 전통식탄화 로 백탄 $1.14 \%$, 온열욕 겸용 숯가마 백탄 $1.50 \%$ 이었다. 회분함량에 대하여 Kwon et al.(2011)은 $1.63 \sim 2.71 \%$, Lee and Kim (2010a)은 2.5\%, Kwon et al.(2012)은 변재부 백탄은 2.67\%, 심재부 백탄은 3.10\%로 보고하고 있어 본 연구의 백탄은 다소 낮은 회분함량을 보여주었다. 휘발분은 전통식탄화로 백탄 $7.05 \%$, 온열욕 겸용 탄화로 백탄 $9.10 \%$ 로 온열욕 겸용 탄화로에서 생산된 백탄이 다소 높게 나타났다. 휘발분의 함량은 연구자에 따라 다소 차이가 있어, Lee and Kim (2010a)은 $9.9 \%$, Kwon et al. (2011)은 3.4\%로 보고하고 있다. 고정탄소는 솣 생산 전용 솣가마 백탄 $82.20 \%$, 온열욕 겸용 솣가마 백탄 80.19\%로 나타났다. Kwon et al.(2011)은 백탄의 평균 고정탄소 87\%, Lee and Kim(2010a)은 고정탄소 79.3\%를 보고하고 있어 본 연구의 백탄의 고정탄소량은 일반적인 목탄과 큰 차이가 없는 것으로 나타났다. 본 연구에 사용된 목탄은 국립산림과학 원에서 고시(제2017-9호)한 목재제품의 품질인증기준(National Institute of Forest Science, 2017)을 충족하는 우수한 특성을 보여주었다.

\section{2 밀도, $\mathrm{pH}$, 흡습성}

Table 2는 솣 생산 전용 숯가마에서 생산된 목탄과 온열욕 겸용 솣가마에서 생산된 백탄에 대한 밀도, $\mathrm{pH}$, 흡습성 결과를 나타낸 것이다. 전통식솣가마에서 생산된 백탄의 밀도는 $0.45 \mathrm{~g} / \mathrm{cm}^{3}$, 온열욕 겸용 숯가마에서 생산된 백탄의 밀도는 $0.47 \mathrm{~g} / \mathrm{cm}^{3}$ 로 온열욕 겸용 솣가마에서 생산된 백탄이 약간 높게 나타났다. $\mathrm{pH}$ 는 숯 생산 전용 숯가마 백탄 9.29 , 온열욕 겸용 숯가마 백탄 9.59로 나타났다. 일반적으로 목탄의 특성은 탄화온도에 크게 영향을 받는데, $\mathrm{pH}$ 는 탄화온도가 증가할수록 알카리성을 띠는 것으로 알려지고 있다(Jo et al., 2008). Kwon et al.(2012, 2013)은 굴참나무를 이용하여 탄화온도의 증가와 함께 목탄의 $\mathrm{pH}$ 는 증가하여 강알카리성을 나타낸다고 보고하였고, 최근 Hidayat et al.(2017)은 열대재의 미성숙재를 이용한 탄화연구에서 탄화온도 증가에 따른 $\mathrm{pH}$ 의 증가를 보고하고 있다. 이와 같이 높은 온도에서 제조된 목탄은 높은 $\mathrm{pH}$ 를 갖는데, 이러한 이유는 탄화온도에 따라 생성되는 산성이나 염기성의 관능기 종류 및 양의 차이에 의한 것으로 저온탄화물에서는 산성의 관능기가, 고온탄화물일수록 염기성의 관능기가 풍부해지기 때문으로 생각되고 있다 (Jo et al., 2006). 상대습도 $80 \%$ 조건에서 측정한 목탄의 흡습성을 분석한 결과, 전통식탄화로의 백탄의 평형함수율은 $10.85 \%$, 온열욕 겸용 솣가마 백탄의 평형함수율은 $9.88 \%$ 로 비슷한 흡습특성을 보여주었다. 최근의 주택은 단열과 차음 설계 등으로 인하여 밀폐된 실내 환경이 되기 쉽다. 이때 밀폐된 환경은 고습도 조건으로 되기 쉽고, 이에 따라 실내 VOCs, 유해 균 및 곰팡이류 등이 문제 되면서 친환경소재를 이용한 습도조절, 냄새제거 등에 많은 관심을 가지고 있어 목탄의 활용이 적극 추천되고 있다(Lee and Kim, 2010a; Lee and Kim, 2010b).

\section{3. 발열량, 경도, 정련도}

Table 3은 전통식솣가마에서 생산된 목탄과 온열욕 겸용 숯가마에서 생산된 백탄에 대한 발열량, 경도, 정련도를 분석한 결과이다. 전통식숯가마 백탄의 발열량은 8,139 kcal/kg, 온열욕 겸용 숯가마 백탄은 $8,095 \mathrm{kcal} / \mathrm{kg}$ 로서 비슷한 결과를 보여주었 다. 두 솣가마에서 생산된 목탄의 발열량은 국립산림과학원에서 고시(제2017-9호)한 목재제품의 품질인증기준(National Institute of Forest Science, 2017)에서 A등급에 해당하는 값으로서 우수한 품질의 목탄임이 입증되었다. 정련은 숯을 구울 때 최종적으로 고열처리과정으로 이 과정에서 목탄의 품질이 달라진다. 정련도는 목탄표면의 전기저항을 측정하여 숯의 탄화정 도를 나타내는 것으로 $0 \sim 9$ 까지 10단계로 나타내고 0 에 가까울수록 우수한 품질을 목탄을 의미한다. 또한 목탄의 경도는 목탄표면의 단단함을 나타내는 것으로 숫자가 높을수록 단단한 것을 의미한다. 정련도와 경도는 숯 생산 전용 솣가마 백탄과 온열욕 겸용 숯가마에서 생산된 백탄 모두 같은 우수한 특성을 보여주었다.

\section{4 해부학적 특성}

Fig. 2는 전통식숯가마와 온열욕 겸용 숯가마에서 생산한 백탄의 3단면을 주사전자현미경으로 관찰한 사진이다. 일반적으로 목탄의 횡단면은 목재의 횡단면과 거의 차이가 없으나 세포벽이 균질한 구조를 보여주고 도관의 형태가 접선방향 혹은 방사방향 
으로 다소 변형되거나 찌그러져서 나타나는 것이 특징이다. 방사단면과 접선단면도 목재의 특징과 큰 차이는 없고 각 세포의 벽이 균질한 구조로 비결정성의 형태를 보여주고 있다. 목탄의 구조는 제조온도에 따라 차이가 나타나는 것이 보고되어왔고

(McGinnes et al., 1971; Elder et al., 1979; Cutter et al., 1980; Kim and Hanna, 2006; Kwon et al., 2009), 고고학적인 측면에 서도 수종식별과 관련하여 목탄의 구조를 연구하여 왔다(Prior and Alvin, 1983, 1986; Prior and Gasson, 1993; Angeles, 2001; Eom and Xu, 2010). 특히, 저자 등(Kim and Hanna, 2006)은 여러 온도로 제탄된 목탄을 주사전자현미경으로 분석한 결과에서 제조온도에 따른 해부학적 특성의 차이를 자세히 구명하였다. 즉, 본 연구에 사용된 백탄과 거의 동일한 온도인 $1000^{\circ} \mathrm{C}$ 에서 제조된 목탄은 $400-800^{\circ} \mathrm{C}$ 에서 제조한 목탄에 비해 도관이나 유세포의 파괴 및 변형이 크고 세포벽도 크게 얇아지는 것을 보고하였다. 또한 목재 내에 존재하는 칼슘결정의 표면이 $400-600^{\circ} \mathrm{C}$ 에서 제탄한 목탄에서는 매끄러운 외형을 가지지만, $800^{\circ} \mathrm{C}-1000^{\circ} \mathrm{C}$ 에서 제탄한 목탄에서는 칼슘결정 표면에 작은 공극들이 나타나 스폰지 모양으로 관찰된다고 보고하였다.

\section{4. 결 론}

전통식탄화로와 온열욕 겸용 탄화로에서 생산된 백탄의 특성을 조사한 결과는 다음과 같다.

1. 전통식탄화로와 온열욕 겸용 탄화로에서 생산된 백탄에 대한 공업분석에서 함수율은 $10 \%$ 미만, 회분은 $3 \%$ 미만, 휘발분은 $10 \%$ 미만, 고정탄소는 $80 \%$ 이상으로 나타나 우수한 품질을 나타냈다.

2. 밀도는 $0.45 \mathrm{~g} / \mathrm{cm}^{3} \sim 0.47 \mathrm{~g} / \mathrm{cm}^{3}, \mathrm{pH}$ 는 9.29 9.59, 상대습도 $80 \%$ 조건에서 흡습성은 $10 \%$ 내외로서 양 탄화로의 백탄 간에 차이가 거의 없었다.

3. 발열량은 $8000 \mathrm{kcal}$ 이상, 정련도는 0, 경도는 12 로서 양 탄화로의 백탄 간에 차이가 없었고 우수한 특성을 나타냈다.

4. 주사전자현미경으로 관찰한 3단면의 구조는 차이가 없었다.

이상의 결과로부터 온열욕 겸용 탄화로에서 제탄된 백탄은 기존 전통식탄화로에서 생산된 백탄과 유사한 특성을 보여주었고, 국립산림과학원의 목재제품품질인증 기준을 충족하는 우수한 품질의 백탄으로 판단되었다. 